\title{
Thank you, Professor Heinrich Herzog
}

In paying tribute to Professor Herzog, one of the longest-serving editors of a Karger publication, I would like to adopt a more personal approach than is usual with such matters. This is not to say that we do not enjoy a personal and friendly relationship with all the other editors and authors of our publications, but that Respiration has always had a special place in our publishing program.

I can still recall particulars relating to the founding of the journal by my father Heinz Karger in 1944, then called the Schweizerische Zeitschrift für Tuberkulose. These were extremely difficult times, but a German-language publication with occasional contributions in French and Italian seemed to be appropriate for the members of the Swiss Society against Tuberculosis. Some of the representatives of this society, such as W. Loeffler in Zurich and I. Uehlinger in St. Gallen, were among the first editors of the journal with whom my father particularly enjoyed working.

The journal grew in a most successful manner and soon after World War II established itself beyond the borders of Switzerland; gaining recognition throughout Europe. This also necessitated new faces on the editorial board. In 1962 it was considered appropriate to enhance the international appeal of the journal by renaming it Medicina Thoracalis and publishing it in German, English and French. The idea was to introduce an international forum available to scientists from around the world for the dissemination of their research to a broader audience.

The year 1962 also saw an important change in the editorial management of the journal. By that time, research in the field of pathophysiology, clinic and therapy of the organs of the thorax had increased dramatically. These developments were recognized by Professor Herzog who at that time assumed editorial responsibility for the jour- nal. Since it had become clear by 1968 that English had started to establish itself worldwide as the primary scientific language, the journal was renamed Respiration, the title it has retained until today. 'English articles preferred' was the policy pursued initially, but this shifted in practice to the almost exclusive use of English, a development which, while it did not initially meet with universal approval, merely reflected the growing international success of the publication. The world-wide popularity of the journal was not least a consequence of the distinguished international reputation of Professor Herzog, who has almost single-handedly transformed it into a truly internationally recognized European publication well able to compete with journals published in English-speaking countries.

After a transitional period of approximately one year, full editorial responsibility for the journal will be assumed by Dr. C.T. Bolliger of Basel. It is our hope that he will be able to profit from and use Professor Herzog's vast managerial experience for as long as possible and whenever the need arises. Dr. Bolliger has also agreed to continue our series Progress in Respiratory Research, a series which aims to complement Respiration and the two new volumes of which have already been published.

Finally, I would like to express my deep-felt gratitude to Professor Herzog for his untiring support of the journal and the publishing house as a whole on many occasions during the course of our collaboration. I am also deeply indebted to Mrs. Herzog, who, I am sure, must often have missed his presence at home because of the many responsibilities, including managing this journal, which he has had to fulfil.

I thank you,

Thomas Karger

\begin{tabular}{ll}
\hline KARGER & ( ) 1998 S. Karger AG, Basel \\
$\begin{array}{l}\text { Fax +4161306 12 34 } \\
\begin{array}{l}\text { E-Mail karger@karger.ch } \\
\text { www.karger.com }\end{array}\end{array}$ & $\begin{array}{l}\text { This article is also accessible online at: } \\
\text { http://BioMedNet.com/karger }\end{array}$
\end{tabular}

